\title{
The World Bank and the "Equity Agenda": An Assessment After Ten (or So) Years
}

\author{
Joel E. Oestreich
}

The theme of the World Bank's 2006 World Development Report was Equity and Development. This article reviews the origins of the 2006 WDR, and why this was a controversial and political decision. It explains why equity is different from equality. It then considers what the World Bank and other agencies are doing to promote greater equity. Proequity policies require concern about distribution of both wealth and income, and the things that create greater opportunity. These issues are framed in terms of what some economists refer to as the "growth-inequality-poverty triangle." Resolving some of the contradictions of this triangle-how pro-growth policies and a concern for the distribution of gains does or does not resolve the problem of absolute poverty - explains many of the problems that remain. KEYWORDs: development, equality, equity, poverty, rights-based approach, sustainability, World Bank.

THe TITLE OF THE WorLd BANK'S 2006 WorLd DeVelopment RePort (WDR)-A document issued annually by the Bank, on varying themes-was Equity and Development. Presciently, the report's authors focused on the related problems of equity and equality, within states and between states and regions: "presciently" since the issue of equity has received increasing attention in the international community in recent years, exemplified by Thomas Piketty's Capital in the Twenty-first Century. ${ }^{1}$ Inequality has become one of the defining challenges of the current economic situation.

The tenth anniversary of the Equity and Development report presented a good opportunity to take stock of World Bank efforts to implement its ideas on equity and inequality. In this article, I argue that while the World Bank deserves some credit for getting these issues on the international development agendafor example, in the creation of a specific equity approach at the UN Children's Fund (UNICEF) and a clear equity agenda at the UN Development Programme (UNDP) - and while it has undertaken some important internal reforms to implement a coherent equity agenda, the concept still suffers from being underspecified and incompletely understood. Much of this is because the idea of equity itself is fraught with philosophical and practical imprecision. Knowing what equity means, and how it is distinguished from the related concept of equality, is not easy; and both terms raise complex political issues. It can be difficult to distinguish an equity agenda from the simpler, more established priority of fighting 
poverty. These problems, I conclude in this article, can be framed in the context of the "growth-inequality-poverty triangle" first identified by World Bank economists. An equity agenda involves the interaction of all three sides of the triangle, but their relationship with each other is still not fully specified.

This is important since equality has, again, become a topic of tremendous concern in the international system as well as within many individual countries, not least the United States. And Sustainable Development Goal 10, "Reduce Inequality Within and Among Countries," is only one solid representation of this globally. But without better specification of how inequities are to be tackled, these goals will be harder to achieve. Yet they are likely to only increase in importance in the future. In this article, I review the origins of the Equity Agenda at the World Bank, explaining why it arose when poverty alleviation was already the ostensible goal of the Bank's efforts. I explain what equity means in this context, and how it differs from equality: a vitally important distinction, given the current politics of development. I then review how the Bank - and other related agencies - have changed their development work to address the issue, and also the extent to which their work has not changed, and why not. Finally, I address the growth-inequality-poverty triangle. The overall point of this article is to show that while equity is a meaningful concept and does imply the need for real change in development thinking, this change is hampered by several misunderstandings. Development agencies need to clarify these important issues before the agenda can be effectively implemented.

\section{Origins of the Equity Agenda}

The people most involved with writing the 2006 World Development Reportincluding Francois Bourguignon, the Bank's then chief economist - trace its origins back to conversations during a Bank conference in Oaxaca, Mexico. The participants (including economists who would be principal authors of the 2006 report) were dissatisfied with the way that existing development policies ignored how the benefits of growth were distributed. ${ }^{2}$ Publication of the groundbreaking book Redistribution with Growth ${ }^{3}$ had "introduced these ideas" (in Bourguignon's words $)^{4}$ about distributional issues, and the World Bank had put poverty reduction at the heart of its work since around that time. ${ }^{5}$ However, the neoliberal policies of the Washington Consensus ${ }^{6}$ continued to dominate Bank thinking. Although poverty reduction remained the cornerstone of World Bank goals, the emphasis remained on reducing poverty through sound macroeconomic policy and promoting economic growth, ${ }^{7}$ rather than directly addressing issues of fair (however defined) distribution.

In interviews, Bourguignon and others have referred to the theme of equity as a "manifestation of something in the air," a growing lack of confidence in the standard neoliberal model of growth. ${ }^{8}$ There was a feeling that the World Bank had strayed from its antipoverty agenda, due to structural adjustment policies. ${ }^{9}$ 
That said, making equity the focus of the WDR in 2006 brought political problems with it. The authors of the WDR 2006 in particular were well aware of the fallout over the 2000 WDR Attacking Poverty. As Robert Wade documents, ${ }^{10}$ the 2000 report met resistance both within the Bank and outside (particularly from the US Treasury Department). Although reducing poverty was the central goal of the Bank, many economists felt this was best achieved by promoting growth, not focusing on other factors such as distribution, good governance, and social structures. Also, the 2000 report suggested that poverty reduction required political change, not just sound (but strictly) economic policy. This proved too controversial, as it opened the Bank to charges that it was promoting interference in the internal political affairs of borrowers. The author of the report, economist Ravi Kanbur, ended up resigning due to the resistance he encountered, and some of the report was watered down at the insistence of some of the Bank's executive directors. "We knew we could not go too far," Bourguignon commented in a talk given on the anniversary of the WDR, referring to the fate of Kanbur and the 2000 report. ${ }^{11}$

Nevertheless, Bourguignon, with economists Michael Walton and Francisco Ferreira, had the agreement of then Bank president James Wolfensohn (who would be replaced by Paul Wolfowitz in 2005). They also had the agreement of the Bank's executive directors, although there was some skepticism. The US and French executive directors, in particular, are said to have stressed the need to focus on equity rather than on equality: that is to say, on matters of opportunities and treatment rather than the final distribution of resources. The United States and other Western states had always insisted that speaking of equality of outcomes, or transferring resources from the rich to the poor, was antithetical to the free-market orthodoxy they preferred.

In the end, the 2006 report was designed to skirt political difficulties while still putting the focus on "shared prosperity." The authors made the final report palatable to the executive directors by putting the emphasis on equality of opportunity rather than equality of results. From a practical perspective, lack of opportunity introduced market imperfections and outright failures (e.g., denial of excluded groups to fair credit markets) that held back overall economic progress. ${ }^{12}$ The Bank should be doing more to empower the poor through better education and nutrition, a healthy environment, and a legal and social framework that gives them the tools to prosper. In this sense, it was similar to the idea of rights-based approaches (RBAs) to development, ${ }^{13}$ Amartya Sen's notion of rights as capabilities, and equality of treatment and improved governance as central to the definition and pursuit of development. ${ }^{14}$

\section{Equity, Equality, and the Social Aspect of Development}

The 2006 report begins by defining equity as the ability of individuals to have "equal opportunities to pursue a life of their choosing and be spared from extreme 
deprivation in outcomes." 15 This is a two-part definition, emphasizing poverty alleviation ("extreme deprivation") and also empowerment ("equal opportunities"). The emphasis on equal opportunities has an important political component, as we have seen. The report shows that there is a basic unfairness in the fact that two children, born in different circumstances (one, e.g., to a wealthy white family in Cape Town, South Africa; the other to a poor black family living in Eastern Cape Province) have such differing upbringing, education, nutrition, and ultimately opportunity to make of their lives as they want. The report states clearly that there is a moral issue here - that this is an unfairness that is unrelated to the hard work, intelligence, and worthiness of the two children - and an economic issue.

Although the emphasis is on fairness of opportunity, the report also suggests that economic inequities are bad for overall economic growth. This was not an innovation of the report, although economists have tended to pay too little attention to distributive issues, ${ }^{16}$ but putting it in the report was a fairly big step for the Bank. Much economic research held that some inequality (if not inequities) is often good for overall economic growth, and that part of the economic modernization process included a period of growing inequality. The Kuznets Curve suggests that poor countries start off with little inequality since everyone is fairly poor; they go through a period of rising inequality as overall wealth rises, and then that wealth is eventually spread more evenly as the economy matures. ${ }^{17}$ Even some quite sympathetic to equity concerns still insist that growing inequality is inevitable and beneficial in the long run. ${ }^{18}$ As Bourguignon notes, the WDR 2006 moves beyond distribution and its effects on growth, and notes the economic effects of lack of opportunity and the ensuing market imperfections. The WDR 2006 also pays attention to "poverty traps": 19 inequities that lead to persistent intergenerational poverty that thwart poverty reduction strategies. Distribution of opportunity, not just results, is front and center as a policy issue.

Another noteworthy part of the WDR 2006 is a mention of inequalities and inequities both within and between countries. It notes that inequity within countries were real, persistent, and a hindrance to development, and needed to be addressed, and also that the same factors between rich and poor countries were also a matter of concern. "Why," the report asks, "is it objectionable for, say, Turkish women to have inferior opportunities and outcomes compared with Turkish men, but not so objectionable if the comparison is between Turkish men and English women?"20 The report did not go so far as to make specific recommendations about the transfer of wealth from the richer to the poorer countries, but even raising the issue of global inequality was a fairly radical step for the Bank. Like the idea of a "right to development," global inequality as an issue suggests that the rich do owe the poor something at the global scale. ${ }^{21}$

The goal of the equity agenda is not a radical leveling of all peoples' situations, and the Bank (and most economists) agree that some inequality is an economic necessity as well as morally acceptable. Hopefully, as a society matures, 
the benefits of growth will spread more widely but this does not inevitably happen, so good policies may be called for to spread the benefits of growth. "The evidence of particular countries would suggest that growth can be more or less pro-poor, and therefore inequality reducing - and so the effects would seem to depend crucially on the strategy adopted." 22 Instead of radical leveling, equity becomes a combination of equal opportunity and protection from absolute deprivation. To advance equity, governments and development agencies should "level the playing field" through policies around education, nutrition, access to credit and economic opportunities, fair application of the law, and other areas that could otherwise give some people a greater advantage in life than others. Outcomes will vary among individuals. But life chances will be equalized and the poorest of the poor will be protected from the worst forms of poverty. The meaning of equity will also vary between countries: promoting equity in, say, France, will mean helping people who are already quite wealthy by the standards of, say, Vietnam. ${ }^{23}$ Reducing poverty and achieving important development goals over time require that development agencies consider distribution, opportunity, and the levelness of the playing field. ${ }^{24}$

It must be noted here that the difference between equality and equity is sometimes hard to define. Leveling the playing field for many will still require close scrutiny of outcomes, not just opportunities, and some substantial redistribution. After all, how else can we know if the drive for equity has been successful, if not by an overall level of equality in outcomes - not at the individual level, but in the average income of various groups of people such as across ethnic groups or between genders? We know that discrimination or generational poverty is being eliminated when the outcomes between groups are less uneven. Other efforts have been made, it must be noted, to measure equality of opportunity, ${ }^{25}$ including work by World Bank economists, but ultimately some sort of between-group comparison of outcomes is unavoidable.

More importantly, pursuing equity may well require some redistribution of resources, to create the conditions that allow equality of opportunity. As the 2006 report notes, "A concern with equality of opportunity implies that public action should focus on the distributions of assets, economic opportunities, and political voice, rather than directly on inequality in incomes." ${ }^{26}$ This implies that transfers of money through taxation and other means are necessary to provide the schools, health care, legal resources, and other empowering measures that will allow real equity of opportunity. Development agencies cannot shy away from this implication.

Equity requires not just providing physical resources or even capabilities such as education and better nutrition. It also requires a respect for the right to equal treatment, access to a functioning and fair legal system, political voice and participation, and a number of other civil and political rights to protect persons while they try to make the most of their situations. ${ }^{27}$ Recognizing this leads international organizations into the tricky terrain of human rights promotion. The 
authors of the WDR 2006 understood this, although the report studiously avoided discussing equity in rights terms for political reasons. Still, distinguishing equity of opportunity from equality, and from an emphasis on human rights, is tricky and asks politically sensitive questions about overall distribution of wealth and income.

\section{Implementation of the Equity Agenda}

Preparation of the WDR is one thing, but it does not bring with it any automatic reforms. Staff must then advocate for policy changes to implement its ideas. One concrete and important change that has come - at least partially - from the new emphasis on equity is the implementation by the World Bank of the "twin goals," adopted by the Bank's Development Committee in 2013. Less a direct result of the 2006 report than another indication that equity was a growing matter of international concern, the goals called for: (1) reducing the rate of extreme poverty (those living on $\$ 1.25$ per day) by 2013; and (2) promoting shared prosperity, defined as "fostering income growth of the bottom 40 percent of the population in every country.... The goal of promoting shared prosperity reflects the World Bank Group's commitment to improving the welfare of poor and vulnerable people everywhere. $" 28$

It is important to see that shared prosperity and ending poverty are distinct, albeit closely connected, concepts. In wealthier countries, shared prosperity might mean improving the lot of many people who are not, by global standards, poor. And a country that has a relatively decreasing number of people living in poverty will nevertheless be failing to share prosperity if the remainder of the bottom 40 percent of the income distribution - those who may not be poor in absolute terms - are not benefiting from growth. A 2015 monitoring report by the Bank and the International Monetary Fund notes that equity and shared prosperity are goals in both developed and developing countries, although their meaning, and the challenges they bring up, will be different in different contexts. ${ }^{29}$

Shared prosperity should not be underestimated as a change in Bank strategy or goals. "Fighting poverty has always been a central mission of the World Bank Group," according to a Bank strategy document: "As a new element, the two goals add concrete, measurable dimensions to the fight against poverty. Just as important, the goal of shared prosperity reflects the aspiration for rapid, sustained, and inclusive increases in living standards .... The World Bank Group is committing itself to putting these goals at the very center of its work - and thus maximizing its impact on global economic development." ${ }^{30}$ As global trends continue to worsen the divide between rich and poor, the role of the Bank is not just to reduce poverty, but to fight these trends. It is hard to say how much real change there has been in policy; the Bank is not an easy organization to change, with powerful bureaucratic reasons to favor the status quo over major adjustments. ${ }^{31}$ 


\section{Specific Policies Within the World Bank}

As signs of concrete operational change, two innovations emerge in particular. The first of these is the introduction of the Systematic Country Diagnostic (SCD) process into World Bank planning. Preparation of the SCD is done before creation of a country strategy, replacing a less formal set of analyses. While it might seem like a relatively minor revision of the process of creating strategies - and while the World Bank is no stranger to initiatives that create paperwork, but no real policy change ${ }^{32}$ - key staff insist that at the least it represents a real change in procedure, directly tied to achievement of the twin goals, and early evaluations are promising. ${ }^{33}$ "The SCD is intended as a reference point for client consultations on priorities for the WBG country engagement. Additionally, it can help the broader dialogue between a country and development partners to focus efforts around high impact goals and activities." 34 The point of the SCDs is to focus development planning on how to achieve the twin goals in each country, rather than only on what products the Bank has to offer.

The framework of the SCD process identifies three key elements that have to be kept in mind: the amount and extent of growth; whether the growth is inclusive; and the risks to the sustainability of growth and its ability to reduce poverty. "Inclusive growth, according to the framework, can be achieved by ensuring equal access to services; enhancing agency, voice and freedom; and ensuring that gains from growth, such as through jobs, are distributed equitably." 35 So SCDs are expected to consider inclusiveness, and to define inclusiveness as a process of providing equitable treatment, access, and rights. Following from the definition of equity presented earlier, the SCD process recognizes that equity and poverty reduction are about more than simply encouraging growth, or even encouraging a better distribution of growth; they are about enabling people to be equal in how they are treated and the opportunities presented to them.

An assessment of the SCD process found that the reports did a fairly good job of identifying the drivers of shared prosperity and incorporating them into planning, although how successful the results will be cannot be known for a while. It notes, for example, that in some countries growth was correlated with decreased inequality while in others (e.g., Indonesia) it seemed to increase inequality (as measured by the Gini coefficient). Growth itself is not necessarily a solution to equity. The assessment also noted that good governance - capacity, transparency, and similar factors-featured prominently in SCDs. ${ }^{36}$

A good example of an SCD approaching these issues is that of Botswana. After noting that Botswana has seen substantial economic growth that has placed it in the category of a middle-income country, the SCD posits that the benefit of this growth has not reached the poorest and has only enhanced inequality. Along with suggesting the expected interventions-improved educational quality, better nutrition, and so forth - the report asserts the need for governance reform, diversification of revenue streams, and improved connectivity for all citizens. ${ }^{37}$ It emphasizes moving away from natural resource exploitation and 
toward a more "inclusive" economy that provides broad-based employment for the poorest Botswanans. Conversely, the Peru SCD notes a "virtuous cycle of growth and shared prosperity" that needs to be nurtured by "provid[ing] all Peruvians with access to better-paying income opportunities and to unleash[ing] the private sector's potential to create ... better-paying jobs." 38 Yet the Peru SCD also notes potential problems toward shared prosperity such as the concentration of poverty among indigenous groups, Afro-Peruvians, and the urban poor; poor service provision; and low productivity growth. A review of SCD documents overall suggests inclusiveness is fairly well incorporated, although sometimes without enough specifics.

A second key element in operationalizing the twin goals is the incorporation of equity and inclusiveness into Development Policy Loans (DPLs). Development Policy Operations were created by the Bank in 2004 to help member countries "achieve sustainable growth and poverty reduction through a program of policy and institutional actions. [DPLs] support a program of policy and institutional actions, which could, for example, improve public finances or the investment climate, enhance human development, or the targeting of a cash transfer program." 39 Over the past decade, DPLs have accounted for about 30 percent of Bank lending, a substantial amount overall. ${ }^{40}$ DPLs are expected to be quick-disbursing (in contrast to infrastructure loans, which often are phased over time) and to be aimed at transformational reforms in developing countries through government reform, capacity building, and large policy changes.

DPLs are seen as an important vehicle for pursing innovative policies to achieve equity in borrower countries - a way of moving past traditional growthcentered projects, and instead making the sort of "transformational change" that will lead to growth with equity that leaves fewer people behind ${ }^{41}$ The notion of transformational change - certainly easier said than done - is to use Bank funding to address serious systematic obstacles to growth and poverty alleviation, and have "large-scale impact in an area of a major development challenge .... That remove critical constraints to development; cause or support fundamental change in a system; have large-scale impact at the national or global level; and are economically, financially, and environmentally sustainable." 42 Differentiating shared prosperity from mere development requires a transformational development policy that does not just grow the economy, but changes how it works for the poor. While DPLs cover a wide variety of different policy prioritiesfrom environmental protection to anticorruption efforts to public sector reform to macroeconomic restructuring - they are seen by many Bank staff as the most important lending instrument for pursuing innovative equity-oriented policies. And while DPLs are not themselves a result of the twin goals, their use to promote equity is somewhat innovative, a sign of (slowly) shifting priorities.

As examples of DPLs aimed at promoting equity and sharing prosperity, the Bank points to the Promoting an Inclusive, Equitable and Efficient Social Protection System program in Colombia that improves labor conditions, strengthens 
the system for providing and monitoring a social safety net, and improves the situation of the elderly; the Rwandan program to entirely overhaul the social safety net system; and the program in Peru aimed at, among other things, improving urban infrastructure to help the poor use public transportation to get to and from their place of work. Bank policy states that

\begin{abstract}
Development Policy Financing (DPF) aims to help the borrower achieve sustainable poverty reduction through a program of policy and institutional actions, for example, strengthening public financial management, improving the investment climate, addressing bottlenecks to improve service delivery, and diversifying the economy. This represents a shift away from short-term macroeconomic stabilization and trade liberalization reforms of the 1980s-1990s towards more medium-term institutional reforms. ${ }^{43}$
\end{abstract}

These medium-term reforms specifically tie DPLs to a shift away from earlier Bank thinking, as noted in the first part of this article.

DPLs are, again, closely tied with the transformational growth strategy of the World Bank. Transformational engagements are also seen as working in larger time frames, and as being related to key social issues cutting across social groups - in other words, a recognition that shared prosperity and equality of opportunity require more than just successful traditional development thinking. Transformational engagement is meant to recognize the difficulty of using development assistance to bring about equity and equality of opportunity. To the extent that DPLs represent real change, they highlight how the equity agenda differs from business as usual, but the full extent of that change is still being determined.

\title{
Equity and the Wider UN Family
}

The Bank considers itself first and foremost an ideas and knowledge leader, ${ }^{44}$ and its policy innovations can have wide repercussions within the larger development community. It is important to see what concrete changes have resulted. The UN Development Programme, the primary development arm of the UN Development Group, has also embraced the concept of equity as a primary development objective, at least rhetorically. In committing itself to promotion of the Sustainable Development Goals (SDGs), UNDP has embraced Sustainable Development Goal 10, on inequality, and made that an important programming goal. The 2011 Human Development Report-UNDP's counterpart of the WDR of the World Bank - was titled Sustainability and Equity, directly connecting equity with the notion of sustainability and the SDGs. Subsequent UNDP reports have both distinguished equity from inequality and tied them explicitly together, again with a reference to Sen's approach to equality of opportunity and capabilities. ${ }^{45}$ In fact, equity fits well with the overall notion of a rights-based approach to development, noted above. ${ }^{46}$ RBAs already focus on the political aspect of development, in particular empowerment of underserved groups or those at the political margins, 
and disaggregation of data to identify those who have been left behind (rather than paying too much attention to overall development indicators, which hide disparities and inequities). Where this is done correctly, RBAs pay attention to exactly what an equity approach should be addressing: education, voice, political participation, access to justice, and other empowering factors for those who have historically been left behind.

Similarly, the UN Children's Fund has committed itself to a rights-based approach, guided primarily by the Convention on the Rights of the Child. UNICEF, too, considers political voice, empowerment, and disaggregation of data to find vulnerable groups to be central to its understanding of RBAs, at least in the best cases. Not surprisingly, UNICEF's focus is largely on empowerment through education, proper nutrition, and child and maternal health care, but the "every child, everywhere" motto also commits it to making sure that it reaches the most vulnerable populations. ${ }^{47}$ As UNICEF's website indicates, "The equitybased approach in UNICEF's programmes and policies seeks to understand and address the root causes of inequity so that all children, particularly those who suffer the worst deprivations in society, have access to education, health care, sanitation, clean water, protection and other services necessary for their survival, growth and development." 48

The World Health Organization has also incorporated issues of equity and equality into its official programs, in pursuit of Sustainable Development Goal 10 and generally as part of the goal of better health outcomes. It recognizes that social equity and addressing discrimination and other factors are key to improving global health. ${ }^{49} \mathrm{UN}$ Women has built much of its programming around equityas well as a measure of substantive equality - for women around the world, and also speaks of equality of opportunity as well as other forms of equality. These programs, too, closely integrate the notion of equity with that of a rights-based approach - a reminder that the initial authors of the WDR saw the connection between human rights promotion and equity. It is, perhaps, not surprising that the other agencies are more explicitly able to make that connection since they are not as hamstrung as the World Bank is in terms of discussing human rights. In their work, the connection is more explicit and more instructive of the wider implications of an equity agenda.

\section{Three Challenges to Equity in the Future of the World Bank}

The incorporation of "reduced inequality" as Sustainable Development Goal 10, again, highlights the extent to which inequality and inequity have gained traction on the international agenda. There remains a long way to go in making inequality and inequity central (and well thought out) in development work.

As noted in the first section of this article, the World Bank faces three interlocking challenges: distinguishing the equity agenda from a more traditional pro-poor set of programs; finding the right balance between promoting equity 
and promoting growth (with the assumption that growth will ultimately benefit everyone); and determining the correct level of inequality to accept, given the assumption that some inequality is both inevitable in growing societies and necessary for growth. Each of these relate to the growth-inequality-poverty triangle represented in Figure 1.

Figure 1 Growth-Inequality-Poverty Triangle

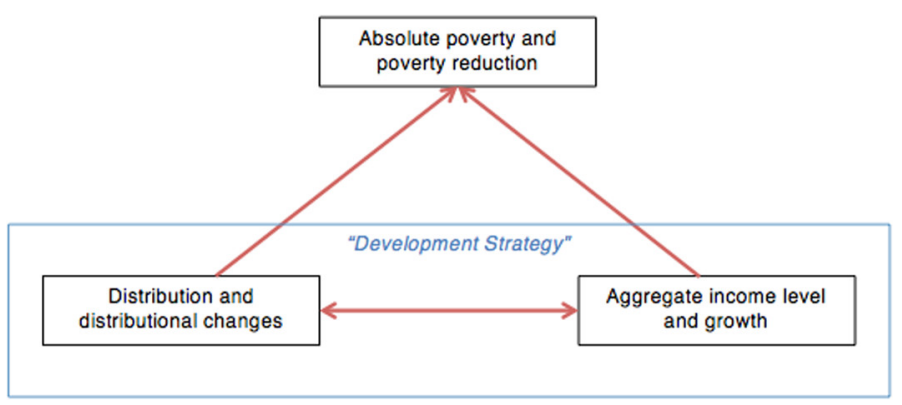

Source: Francois Bourguignon, The Growth-Inequality-Poverty Triangle: Implications for the Development Strategy in Developing Countries (Cairo: Egyptian Center for Econonomic Studies, 2004), p. 4.

In this triangle, both growth (lower right) and reduction in inequality (lower left) affect the reduction of absolute poverty (top). But aggregate growth and distributional changes also have effects on each other. The triangle implies that a reduction in poverty requires looking at both growth and how growth is distributed, and sees poverty, inequality, and growth as part of the same holistic process.

\section{Is an Equity Approach Sufficiently Differentiated from an Antipoverty Approach?}

Bank staff, at conferences and in other fora, have lamented that projects aimed at promoting equity are not always easy to distinguish from pro-poor strategies. This difference is primarily a component of whether a project is simply aiming to help the poor with, say, programs that create jobs or boost incomes and a project that explicitly looks at empowerment, shared prosperity, and promoting equality of opportunity. A pro-poor project might have nothing to do with equality of opportunity or a focus on the bottom 40 percent. Indeed, many projects that are ostensibly equity enhancing in their focus are at heart more traditional projects that help the poor but do not look at the larger definition of equity as the 2006 WDR lays it out. That is, they consider neither the overall distribution of resources nor the rights component of a real equity agenda. ${ }^{50}$ Their notion of what helping the poor involves is more of an old-fashioned perspective. 
It is easy for any set of policies that is shown to be eliminating poverty to be cast as an approach that is equity oriented. In the easiest cases taxation policies that effect a transfer from wealthier to poorer people might be seen as promoting equity, and so would income generation policies to help the poor, or, indeed, any set of policies that generate growth when that growth does benefit the poorest people in society. Promoting equity and equality of opportunity is a political process as much as an economic one, as we have seen. It implies that the poor are being empowered to take control of their own lives, to live up to their potential, and to fight discrimination and marginalization. In this respect, other agencies are ahead of the World Bank.

Also, equity requires not just a focus on distribution between rich and poor, but between-types distribution; that is, whether certain groups are being left behind. The Millennium Development Goals have been accused, for example, of having a "blind spot" in that their targets encouraged a focus on improving the lives of those easiest to reach. ${ }^{51}$ Ultimately, this is a matter of rights promotion: recognizing the rights to equal treatment of all groups, and promoting those rights through development assistance. Rights are not all that is required, of course; many macroeconomic factors, as well as good inclusive project design, can help share prosperity within a society without specifically looking at rights. ${ }^{52}$

Generally speaking, key World Bank staff from the Development Economics and Poverty and Equity groups, in particular, expressed disappointment in interviews that there is not a greater understanding among their colleagues of the difference between an equity agenda — one that focuses on empowerment, equality of opportunity, shared prosperity, and a capabilities approach — and one that merely alleviates poverty. ${ }^{53}$ Much of the challenge is bureaucratic, as promoting real change in any large organization requires time, and traditional ways of doing things always change slowly. There is also simply some time lag in terms of educating people on what the twin goals ought to really accomplish. An equity policy, as staff pointed out, is not the same as a pro-poor one, but delineating the differences is not always so easy.

\section{Should the Emphasis Be on Growth?}

As a related issue, the Bank still struggles with the notion that growth itself ought to be the top priority of development policy. David Dollar and Aart Kraay most notably argue that growth benefits all sectors of the economy equally or, at any rate, there is no systematic bias toward higher quintiles - the rich do not benefit more than the poor from growth, in terms of the share of higher gross domestic product. ${ }^{54}$ This finding and that of other researchers ${ }^{55}$ support those who wish to maintain the Bank's emphasis on overall economic growth rather than equity. There is clearly a bureaucratic bias toward growth-oriented policies - it is, after all, what the Bank has been doing more or less since its founding. There is also a bias born of training: Bank staff often object that they are trained to recognize 
sound economic cases for development projects, and not to think about such normative issues as fairness, opportunity, or equity.

This is reinforced by a general trend among many developing countries back to an emphasis on promoting growth rather than other priorities such as providing basic needs, an attention to equity, or a rights-based approach. ${ }^{56}$ The Bank and other multilateral development institutions have faced some pushback from states who bristle over the intrusive nature of social development policy. These states often resent the implication that development agencies run from Washington, DC, or New York know what is better for their people and economy than they do. While the trend in development for some time has been toward putting more restrictions on the use of aid and promoting more social good, the large majority of funding still goes to more traditional purposes, and the resistance against more social engineering is fairly strong. Added to this is a resentment not only from governments but also from nongovernmental organizations (NGOs) and others about the burdensome reporting requirements that come with a rights-based approach and other human development efforts.

\section{Balancing Equity and Growth}

On the other hand, as we have seen, the 2006 WDR argued strongly that a focus on equity was, in fact, pro-growth in and of itself. Economists have long assumed that some level of inequality is desirable for growth and an inevitable part of a growing economy. In poorer societies, there is not much inequality since nearly everyone is poor. Economic growth will inevitably benefit some people before others. Also, it is desirable that some people profit enough to have sufficient income for savings and to generate investment. And it is assumed that some level of inequality provides incentives for entrepreneurs and other drivers of the economy: tolerating and even promoting inequality is what creates economic activity in the first place. Fighting inequality has often been equated with redistribution through taxation and other policies, which both tamp down incentives and introduce inefficiencies and disincentives into an otherwise well-functioning marketplace.

The 2006 WDR and subsequent work on equity do not insist either that inequalities are necessarily bad, and certainly not that they can be entirely avoided. The emphasis, again, is on equality of opportunity rather than equality of outcomes. Nevertheless, as we have seen, to reach equalities of opportunity, there is going to be a need for some redistribution and some attention to equality of outcomes and resources. And the 2006 report does insist that gross inequality is bad for development: that even if the desired outcome is strictly growth, fighting inequality would still be important. In interviews, Bank staff have expressed concern that the orthodox position that growing inequalities are a necessary and important stage in the growth process will divert attention from equity issues. ${ }^{57}$ The case for equity as a growth strategy adds that economic efficiency argument back in. During the interviews, staff specifically cited the research of Jonathan 
Ostry of the International Monetary Fund, ${ }^{58}$ which argues that gross inequality is detrimental to overall economic growth. This connects the desire for an ethical good - the reduction of inequality and the provision of equal opportunities to all - with the measurable economic and utilitarian good that comes from economic growth. It thus removes many of the political obstacles to a true equity agenda. As with the rights-based approach to development in general, the desire for equity will be best achieved when moral and utilitarian arguments are in alignment with each other.

\section{Conclusion}

As noted above, data on the effectiveness of equity-enhancing policies is often cited by Bank staff as a key element in advancing an equity agenda. ${ }^{59}$ Changing a large bureaucracy is always difficult, and it is even harder when the bureaucrats are trained to pursue data-driven policies. ${ }^{60}$ Moral arguments, such as those made in the 2006 WDR and elsewhere, are not enough; there is the counterargument, never fully refuted, that inequity and growth are inextricably linked. Bank "true believers" in the equity agenda have clearly stated that their greatest desire is for irrefutable economic evidence that there is instrumental value to equity-that inequity really does hinder growth and, therefore, that equity-enhancing policies are pro-growth policies. The nature of equity - how the elements of inequity and inequality should be measured and compared across groups - also needs significant work. Indexes of inequality are available, with the Gini coefficient and Palma ratio being the best known. And the World Bank's Poverty Group, among others, has taken a stab at measuring inequities and defining what inequity means in practical terms; for example, the Equality of Opportunities Index developed by the Latin American and Caribbean office. But measurement and evidence remain vital to help effect real change.

The politics of equity will also remain a serious challenge. An equity agenda, again, is intimately tied to the notion of a rights-based approach to development, and like RBAs it requires serious thought about both positive and negative rights. It requires attention to the distribution of resources within a country, beyond that which comes from a pure operation of the free market. And it requires empowerment of citizens, without which there cannot be real equality of opportunity. These demands come, however, at a time when developing countries are increasingly suspicious of intrusive development initiatives, and more interested in absolute growth. Tying development and growth to the promotion of rights, and making the case that these rights are instrumentally important and thus within the purview of development agencies, will likely be increasingly important, particularly as achievement of Sustainable Development Goal 10 gains traction. If the multilateral agencies cannot convincingly make this case and incorporate these ideas, resistance to the equity agenda may well prove too powerful to overcome. 


\section{Notes}

Joel E. Oestreich is Professor of Politics at Drexel University. He is the author of Development and Human Rights: Rhetoric and Reality in India (Oxford, 2017).

1. Thomas Piketty, Capital in the Twenty-first Century (Cambridge, MA: Belknap Press, 2014).

2. Francois Bourguignon, former chief economist at the World Bank, interviewed by the author, Washington, DC, 20 October 2016.

3. Hollis Chenery, Redistribution with Growth (London: Oxford University Press, 1974).

4. Bourguignon interview.

5. Robert L. Ayres, Banking on the Poor: The World Bank and World Poverty (Cambridge: MIT Press, 1983).

6. See, for example, Stanley Fischer, "Structural Adjustment Lessons from the 1980s," in D.M. Schydlowsky, ed., Structural Adjustment: Retrospect and Prospect (Westport, CT: Praeger, 1995), pp. 21-31; Paul Mosley, Jane Harrigan, and John Toye, Aid and Power: The World Bank and Policy-based Lending, vol. 1 (New York: Routledge, 1995); Stanley Please, "The World Bank: Lending for Structural Adjustment," in R.E. Feinbert and V. Kallab, eds., Adjustment Crisis in the Third World (New Brunswick, NJ: Transaction Books, 1984), pp. 83-98.

7. Catherine Weaver and Ralph J. Leiteritz, “ 'Our Poverty Is a World Full of Dreams': Reforming the World Bank," Global Governance 11, no. 3 (2005): 369-388.

8. Bourguignon interview.

9. Mosley, Harrigan, and Toye, Aid and Power; Sigrun Skogley, "Structural Adjustment and Development: Human Rights - An Agenda for Change," Human Rights Quarterly 15, no. 4 (November 1993): 751-778; World Bank, Adjustment Lending Policies for Sustainable Growth (Washington, DC: World Bank, 1990).

10. Robert Wade, "Making the World Development Report 2000: Attacking Poverty," World Development 29, no. 8 (February 2001): 1435-1441.

11. Comments by Francois Bourguignon at the meeting "Equity and Development Ten Years On,” World Bank, Washington, DC, 20 October 2016.

12. Francois Bourguignon, "Reflections on the 'Equity and Development' World Development Report Ten Years Later," in K. Basu and J.R. Stiglitz, eds., Inequality and Growth: Patterns and Policy (London: Palgrave Macmillan, 2016), pp. 72-100.

13. Ruth Alsop and Nina Heinsohn, Measuring Empowerment in Practice: Structuring Analysis and Framing Indicators (Washington, DC: World Bank, 2005); Andrea Cornwall and Karen Brock, Beyond Buzzwords: "Poverty Reduction," "Participation," and "Empowerment" in Development Policy, Programme Paper No. 10 (Geneva: UN Research Institute for Social Development, 2005); Marianne Hill, "Development as Empowerment," Feminist Economics 9, no. 3 (October 2003): 117-135.

14. Amartya Sen, "Human Rights and Capabilities," Journal of Human Development 6, no. 2 (July 2004): 151-166.

15. World Bank, World Development Report 2006: Equity and Development (Washington, DC: World Bank, 2006), p. 2.

16. Jean-Pierre Cling et al., "Development, a Question of Opportunity? A Critique of the 2006 World Development Report," Development Policy Review 24, no. 4 (Fall 2006): 456. 
17. Simon Kuznets, "Economic Growth and Income Inequality," American Economic Review 45, no. 1: (March 1955): 1-28.

18. Michael Bruno, Martin Ravallion, and Lyn Squire, Equity and Growth in Developing Countries (Washington, DC: World Bank, 1996); John E. Roemer, Equality of Opportunity (Cambridge: Harvard University Press, 1998).

19. Costas Azariadis and John Stachurski, "Poverty Traps," in P. Aghion and S.N. Durlauf, eds., Handbook of Economic Growth (Amsterdam: Elsevier B.V., 2005), pp. 295-384.

20. World Bank, World Development Report 2006, p. 55.

21. Arjun Sengupta, "Right to Development as a Human Right," Economic and Political Weekly 36, no. 27 (July 2001): 2527-2536; Arjun Sengupta, "Conceptualizing the Right to Development for the Twenty-first Century," in United Nations, ed., Realizing the Right to Development (New York: UN, 2013), pp. 67-87.

22. Claire Melamed and Emma Samman, Equity, Inequality and Human Development in a Post-2015 Framework (New York: UN Development Programme [UNDP], 2013), p. 6.

23. Christoph Lakner, Mario Negre, and Espen B. Prydz, Twinning the Goals: How Can Promoting Shared Prosperity Help to Reduce Global Poverty? (Washington, DC: World Bank, 2014), p. 15.

24. Ibid., p. 4.

25. For example, H.G. Francisco Ferreira and Vito Peragine, Equality of Opportunity: Theory and Evidence (Washington, DC: World Bank, 2015); Roemer, Equality of Opportunity.

26. World Bank, World Development Report 2006, p. 3.

27. UNDP, Integrating Legal Empowerment of the Poor in UNDP's Work: A Guidance Note (New York: UNDP, 2010); Cornwall and Brock, Beyond Buzzwords; Hill, "Development as Empowerment."

28. World Bank Development Committee, A Common Vision for the World Bank Group (Washington, DC: World Bank, 2013), pp. i-iii.

29. World Bank, Global Monitoring Report 2014/2015: Ending Poverty and Sharing Prosperity (Washington, DC: World Bank, 2015), p. 7.

30. World Bank, A Stronger, Connected, Solutions World Bank Group: An Overview of the World Bank Group Strategy (Washington, DC: World Bank, 2014), p. 3.

31. Robert Wade, "Greening the Bank: The Struggle over the Environment 19701995," in D. Kapur, J.P. Lewis, and R. Webb, eds., The World Bank: Its First Half-century, vol. 2. (Washington, DC: Brookings Institution Press, 1997), pp. 611-734; Catherine Weaver, Hypocrisy Trap: The World Bank and the Poverty of Reform (Princeton: Princeton University Press, 2008); James Ferguson, The Anti-politics Machine: "Development," Depoliticization, and Bureaucratic Power in Lesotho (New York: Cambridge University Press, 1990).

32. Galit Sarfaty, "The World Bank and the Internalization of Indigenous Rights Norms," Yale Law Journal 114, no. 7 (May 2005): 1792-1818.

33. World Bank, Peru: Systematic Country Diagnostic, Report No. 112694-PE(Washington, DC: World Bank, 2017).

34. Maitreyi B. Das, Social Inclusion in Macro-level Diagnostics: Reflecting on the World Bank Group's Early Systematic Country Diagnostics (Washington, DC: World Bank, 2016), p. 7. 
35. Ibid., p. 8 .

36. World Bank, World Bank Group Country Engagement: An Early-stage Assessment of the Systematic Country Diagnostic and Country Partnership Framework Process and Implementation (Washington, DC: World Bank, 2017), pp. 11-12.

37. World Bank, Supporting Transformational Change for Poverty Reduction and Shared Prosperity: Lessons from World Bank Group Experience (Washington, DC: World Bank, 2016).

38. World Bank, Peru, p. 11.

39. World Bank, 2015 Development Policy Financing Retrospective: Results and Sustainability (Washington, DC: World Bank, 2015), p. 1.

40. Ibid., p. 5.

41. World Bank. Supporting Transformational Change for Poverty Reduction and Shared Prosperity.

42. Ibid., p. 2.

43. Independent Evaluation Group, World Bank, "Development Policy Financing," https://ieg.worldbankgroup.org/topic/development-policy-financing-dpf.

44. Jean-Jacques Dethier, "Producing Knowledge for Development: Research at the World Bank," Global Governance 13, no. 4 (2007): 469-478.

45. Melamed and Samman, Equity, Inequality and Human Development in a Post2015 Framework, p. 2.

46. Sheena Crawford, The Impact of Rights-based Approaches to Development (London: UK Interagency Group on Human Rights Based Approaches, 2008), www.crin .org/en/docs/Inter_Agency_rba.pdf. Paul Gready and Jonathan Ensor, eds., Reinventing Development? Translating Rights-based Approaches from Theory into Practice (New York: Zed Books, 2005); UNDP, Applying a Human Rights-based Approach to Development Cooperation and Programming: A UNDP Capacity Development Resource (New York: UNDP, 2006); UN Development Group, "The Human Rights Based Approach to Development Cooperation Towards a Common Understanding Among UN Agencies" (New York: UN Development Group, 2003).

47. Urban Jonsson, Human Rights Approach to Development Programming (New York: UN Children's Fund [UNICEF], 2003); UNICEF, A Human Rights Based Approach to Education (New York: UNICEF, 2007); UNICEF, Formative Regional Evaluation of UNICEF's Contribution to the Empowerment and Rights Fulfilment of Adolescents in South Asia (Kathmandu, Nepal: UNICEF, 2016).

48. UNICEF, "What Does UNICEF Mean By [an] Equity Approach?" www.unicef .org/about/partnerships/index_60239.html.

49. For example, World Health Organization, Monitoring Health Inequality: An Essential Step for Achieving Health Equity (Geneva: World Health Organization, 2015).

50. Elanna Ianchovichina and Susanna Lundstrom, What Is Inclusive Growth? (New York: World Bank Group, n.d.).

51. Edward Anderson, "Equality as a Global Goal," Ethics and International Affairs 30, no. 2 (July 2016): 189.

52. World Bank Group, Taking on Inequality (Washington, DC: World Bank, 2016), p. 101.

53. World Bank staff, interviewed by the author, World Bank Headquarters, Washington, DC, 29 November 2016. 
54. David Dollar and Aart Kraay, "Growth Is Good for the Poor," Journal of Economic Growth 7, no. 3 (April 2002): 195-225.

55. For example, Michael Roemer and Mary K. Gugerty, Does Economic Growth Reduce Poverty? (Cambridge: Harvard Institute for International Development, 1997).

56. Rosalind Eyben and Laura Savage, "Emerging and Submerging Powers: Imagined Geographies in the New Development Partnership at the Busan Fourth High Level Forum,"Journal of Development Studies 49, no. 4 (April 2013): 457-469.

57. World Bank staff interviews.

58. For example, Jonathan Ostry et al., Redistribution, Inequality, and Growth (Washington, DC: World Bank, 2014).

59. For example, Bourguignon interview; Tamar Manuelyan Atinc, former Vice President (Human Development), World Bank, interviewed by the author, Washington, DC, 21 October 2016.

60. See Maciej Bartkowski, “Analysis of Change Within International Organizations," Paper prepared for the European Consortium for Political Research, Joint Sessions Workshops, Edinburgh, March-April 2003. 